\title{
EXCURSION TO GUILDFORD AND THE NEW RAILWAY WORKS IN PROGRESS THERE.
}

\author{
Saturdar, April 26Th.
}

Director :-Lieut.-Colonel H. H. Godwrin-Auster, F.R.S., F.L.S., F.G.S.

(Report by THE Director.)

Starting from Chilworth Station, the Director first showed the members present the gravel-beds close by, which are about 200 feet above the sea. They then proceeded down the valley of the Tillingbourne, and were shown the gravel-beds at East Shalford, where they are about 30 feet above the present stream, and below the top level of the Neocomian scarp that bounds the Tillingbourne on its right bank at this part of its course. The party then crossed the ridge of the Lower Greensand forming Chantry Dorn, descending into the next valley, which lies on the outcrop of the Gault; and, noticing that formation and the Lower Chalk at the old Chalk-pits, proceeded to Guildford by Pewley Hill.

The cutting at the London Road was next visited, where the Director pointed out the position of a series of high-level sands and gravels, composed almost entirely of material from the Lower Greensand, and having its base 60 feet above the present level of the Wey, and resting on the Woolwich, and Reading, and London Clays, and-east of the railway bridge -on the Chalk. He explained that these deposits are a very much older series than those they had been shown on the Tillingbourne and Peasemarsh.

The newer Drift-gravels, resting on these sands, were also shown, and the spot where a few land-shells had been found was pointed out, attention being directed to the varied character of this Drift and to its very angular, chalky character as it approaches the solid Chalk.

The party then walked through the cutting eastward, Colonel Godwin-Austen showing the spot; at its deepest part, where the mammalian remains were found; and, passing again over the Eocene, and seeing the shell-bed between the London Clay and the Woolwich and Reading series, got into the train of trucks kindly placed at their disposal by Mr. Wills, engineer of the 
works, and were taken to East Horsley, as far as it was then possible to proceed. There they were able to see the deep cuttings in the London Clay excavated by means of a "steam-navry." The greater number then, leaving the train, walked over the Downs by Pebble Farm and Farley Heath to Gomshall Station, for their return journey to town.

\section{REFERENCES.}

Survey Map, No. 8; R.A.C. Godwin-Austen, ' Land-Surfaces beneath the Drift-Gravel,' Quart. Jour. Geol. Soc., vol. xi., 1855, p. 112 ; Prestwich, 'On the Lower Tertiary Strata,' ibid., vol. vi., 1850, p. 252; and Lient.-Col. H. H. Godwin-Ansten and W. Whitaker, 'On the New Railway Cutting at Guildford,' ibid., vol. xl., 1884, p. 599.

\section{ORDINARY MEETING.}

Friday, MaY 2ND, 1884.

J. Loan Lobley, Esq., F.G.S., Treasurer, in the Chair.

The list of donations to the library since the last meeting was read, and the thanks of the Association were accorded to the donors.

The following were elected members of the Association:-

T. J. George, F.G.S.; Edward D. Hearne; Charles Lane ; Edward Lovett; Arthur T. Metcalfe, F.G.S.; B. Thompson, F.G.S.

The following paper was then read :-

'The agricultural geology of England and Wales with reference to the Drift maps of the Geological Surrey,' by W. Topley, F.G.S., Assoc. Inst.C.E.

The publication of this paper is deferred.

\section{EXCURSION TO THE CRYSTAL PALACE.}

$$
\text { Saturday, May 10Th, } 1884 .
$$

Directors :-Dr. D. S. PRICE, F. C.S., Director of the Technological Department, Crystal Palace, and W. Topley, F.G.S., Geological Survey of England.

(Report by W. TOPLEY.)

The party met in the Technological Gallery between 1.30 and 2 p.m. This gallery has been formed, under Dr. Price's superintendence, to illustrate the stages of manufacture of metals, glass, 